\title{
Molecular Testing and Treatment Strategies in RET-Rearranged NSCLC Patients: Stay on Target to Look Forward
}

\author{
Maria Lucia Reale D, Valentina Bertaglia, Angela Listì, Silvia Novello * and Francesco Passiglia \\ Department of Oncology, S. Luigi Gonzaga Hospital, University of Turin, 10043 Orbassano, Italy; \\ realemarialucia@gmail.com (M.L.R.); valentina.bertaglia@gmail.com (V.B.); alisti@live.it (A.L.); \\ francesco.passiglia@unito.it (F.P.) \\ * Correspondence: silvia.novello@unito.it
}

check for updates

Citation: Reale, M.L.; Bertaglia, V.; Listì, A.; Novello, S.; Passiglia, F. Molecular Testing and Treatment Strategies in RET-Rearranged NSCLC Patients: Stay on Target to Look Forward. J. Mol. Pathol. 2022, 3, 24-37. https://doi.org/10.3390/jmp3010003

Academic Editor: Hans Brunnström

Received: 8 December 2021

Accepted: 13 January 2022

Published: 18 January 2022

Publisher's Note: MDPI stays neutral with regard to jurisdictional claims in published maps and institutional affiliations.

Copyright: (C) 2022 by the authors. Licensee MDPI, Basel, Switzerland. This article is an open access article distributed under the terms and conditions of the Creative Commons Attribution (CC BY) license (https:// creativecommons.org/licenses/by/ $4.0 /)$.

\begin{abstract}
RET alterations are recognized as key oncogenic drivers in different cancer types, including non-small cell lung cancer (NSCLC). Multikinase inhibitors (MKIs) with anti-RET activities resulted in variable efficacy with significant toxicities because of low target specificity. Selective RET kinase inhibitors, such as pralsetinib and selepercatinib, demonstrated high efficacy and favorable tolerability in advanced RET-rearranged NSCLC patients, leading to their introduction in the clinical setting. Among the different approaches available for the identification of RET rearrangements, next-generation sequencing (NGS) assays present substantial advantages in terms of turnaround time and diagnostic accuracy, even if potentially limited by accessibility issues. The recent advent of novel effective targeted therapies raises several questions regarding the emergence of resistance mechanisms and the potential ways to prevent/overcome them. In this review, we discuss molecular testing and treatment strategies to manage RET fusion positive NSCLC patients with a focus on resistance mechanisms and future perspectives in this rapidly evolving scenario.
\end{abstract}

Keywords: RET; NSCLC; selpercatinib; pralsetinib; next-generation sequencing; acquired resistance

\section{Introduction}

In recent years, the advent of personalized medicine combined with comprehensive genomic profiling has revolutionized the therapeutic landscape of non-small cell lung cancer (NSCLC), leading to the development of targeted therapies that radically changed cancer care in molecular selected patients [1]. In addition to the well-known oncogene-addicted NSCLC subgroups, including EGFR (epidermal growth factor receptor) activating mutations, BRAF (B-Raf proto-oncogene) V600E mutations, ALK (anaplastic lymphoma kinase) and ROS1 (v-ros avian UR2 sarcoma virus oncogene homolog 1) gene rearrangements, several different drivers (RET rearrangements, HER2 amplification/mutation, KRAS G12C mutation, NTRK 1-3 translocations) were identified in the last decade expanding the list of potential actionable oncogenes [2]. RET chromosomal rearrangements were initially identified in $10 \%-20 \%$ of papillary thyroid cancers. By contrast, RET mutations are the major oncogenic alteration reported in sporadic medullary thyroid cancers (MTC) (50\%) and the most frequent germline mutations found in multiple endocrine neoplasia type 2 (MEN2) [3,4]. The RET proto-oncogene was first identified in lung cancer in 2012 and RET fusions were found in 1-2\% of NSCLC cases examined by four different research groups from United States, Korea and China [5]. Initial reports showed that similarly to other oncogene drivers, RET fusions were typically associated with younger age, female gender, non-smoker status, Asian ethnicity, advanced stage, and adenocarcinoma subtype. However retrospective analysis suggested that RET-positive NSCLC were poorly differentiated compared with other oncogene-addicted (e.g., EGFR, ALK) tumors [6].

Since the beginning, RET fusion genes have been considered mutually exclusive with other molecular alterations. However, a retrospective analysis showed the presence of 
concomitant genomic alterations in 4 of the 12 patients with RET-rearranged NSCLC analyzed, harboring EGFR, MAP2K1, CTNNB1, and AKT1 mutations [7]. Moreover, EGFR mutated patients, experiencing disease progression under EGFR tyrosine kinase inhibitors (TKIs) therapy, may present RET rearrangements as mechanism of resistance [8].

Following RET rearrangement identification, different targeted therapies have been investigated. Multikinase inhibitors (MKIs) have been initially evaluated. Due to their concomitant inhibition of other kinases as vascular endothelial growth factor receptor 2 (VEGFR2) and EGFR, they were, unfortunately, characterized by limited efficacy with significant off-target adverse events and negative impact on health related quality of life, leading to high rates of high grade toxicities and dose reductions in NSCLC patients [9]. These disappointing results have contributed to the further development of selective RET kinase inhibitors, characterized by promising activities and more favorable tolerability.

In this review, we discuss diagnostic approaches and provide evidence to manage RET fusion positive NSCLC patients, summarizing the available therapeutic options, with a focus on resistance mechanisms and future perspectives.

\section{Molecular Pathway}

The RET gene, located in the chromosome 10, is composed by the extracellular region, including four N-terminal cadherin-like domains (named CLD1 to CLD4) followed by a single cysteine-rich domain (CRD), the transmembrane region, and the intracellular region composed by a bipartite tyrosine kinase [10].

RET signaling is involved in the embryonic development of some organs, such as kidney, peripheral and central nervous systems, as well as in the Peyer's patch organogenesis and spermatogenesis process. Furthermore, RET signaling plays a key role in regulating cell proliferation, survival and differentiation process across different neurons subpopulations. The RET ligands include four members of the glial cell line-derived neurotrophic factor (GDNF) family, GDNF, neurturin, artemin and persephin, leading to the autophosphorylation of intracellular tyrosine residues, with subsequent activation of multiple downstream pathways, such as RAS-MAPK, PI3K-AKT, JAK-STAT, PLC $\gamma$ and PKC [11].

The architecture of RET extracellular domain (ECD) was revealed by small angle X-ray scattering (SAXS) and electron microscopy (EM). The EM structure for RET-GFL-GFR $\alpha$ complex has a 2:2:2 stoichiometry: a dimer of GDNF binds two co-receptor molecules that recruits two RET receptors, exhibiting positive cooperativity. This geometry, named ternary complex, reveals a composite ligand-binding site, characterized by a GFR $\alpha 1$-binding hotspot that contacts the CLD containing calcium sites regions, and couples the CRD region ligand recognition leading to the receptor homodimerization. The activation of the kinase domain depends from the intermolecular autophosphorylation of intracellular tyrosine residues, working as docking sites for downstream signaling proteins carrying SRC homology 2 (SH2) or phosphotyrosine-binding (PTB) domains [12-14].

RET proto-oncogene was discovered in 1985 by Takahashi et al. as a gene that REarranged during Trasfections (RET) of DNA extracted from human T-cell lymphoma into NIH-3T3 cells [15]. Grieco et al. showed that the rearrangements were detected in all of the transfectants and of the original tumor DNAs, but not in normal DNA of the same patients, indicating that this genetic lesion occurred in vivo and was specifically related to sporadic tumors [16]. The intracellular region contains a tyrosine kinase domain and tyrosine phosphorylation sites located next to the $C$ terminal region, where two major isoforms, RET9 and RET51, are positioned due to alternative splicing. The latter isoform has stronger tumorigenic activity even if both are co-expressed across different tissues. Although Y1062 is the most important docking site of major pathways, autophosphorylation of certain docking sites specifically gives rise to separate downstream pathways: Y1096 to RAS/MAPK and PI3K/AKT pathways; Y1015 to PLC $\gamma ;$ Y752 and Y928 to JAK/STAT pathway; and Y687 and Y981 to Shp2 and Src kinases, respectively [17].

RET proto-oncogene may be aberrantly activated by point mutation, fusion, or rearrangement. Sporadic mutations and rearrangements have been mainly detected in papillary 
thyroid cancer and NSCLC, while germline mutations have been reported in MEN $[17,18]$. Recently, the applications of next-generation sequencing (NGS) technologies supported the identification of RET alterations in several other malignancies, including pancreatic cancer, salivary gland cancer, colorectal cancer, ovarian cancer, breast cancer, and Spitz tumors. [19-23] To date, more than 35 different RET fusion genes partners have been described, leading to the RET kinase expression and aberrant activation in cell types where both RET and its co-receptors are not normally expressed. In-frame KIF5B (the kinesin family $5 \mathrm{~B}$ gene)-RET fusion occurred predominantly in lung adenocarcinoma (70-90\%), and is composed of $638 \mathrm{~N}$-terminal amino acid residues of the KIF5B protein and $402 \mathrm{C}$ terminal amino acid residues of the RET protein. Coiled-coil domain containing 6 (CCDC6)-RET (RET/PTC1) is the second most frequent fusion described in NSCLC samples, accounting for $10-25 \%$ of the overall RET fusions. Other uncommon RET fusion partners, currently identified in lung cancer patients, include NCOA4, TRIM33, ZNF477P, ERCC1, HTR4, CLIP1, FRMD4, and WAC [24-26]. As with other oncogenic fusions, such as ALK and $R O S 1$, adenocarcinomas are the most frequent histology to carry out $R E T$ rearrangements, followed by adeno-squamous, squamous cell, and neuroendocrine cancers [27].

\section{The Available Techniques to Detect RET Rearrangements}

Since there is not yet a universally accepted standard approach to detect RET rearrangements, several methods may be used in the clinic, including Fluorescence in situ hybridization (FISH), immunohistochemistry (IHC), reverse-transcriptase polymerase chain reaction (RT-PCR), and NGS.

In several pathology laboratories FISH still represents the main technique used for the detection of RET fusions in NSCLC. The break-apart FISH probe is designed to hybridize against the $3^{\prime}$ and $5^{\prime}$ sides of the 10q11.21 RET chromosome region. To date, RET FISH is strongly suggested as a sensitive method to detect RET locus aberrations; however, this technique does not provide any information about the RET fusion partner and is not characterized by high specificity. Indeed the diagnostic sensitivity of FISH for the detection of RET fusions in lung cancer patients was estimated to range between $85.8 \%$ and $100 \%$, while the specificity was reported to range between 62.1 and $96.8 \%$, although it may be underestimated given the positivity cutoff set at $\geq 10 \%$ tumor cells.

FISH presents some limitations, such as inadequate identification of small intrachromosomal rearrangements, since only large gene deletions or amplifications can be detected and quantified by the immunofluorescence probes. As a consequence, FISH may produce some false-positive results, considering that all rearrangements occurring within the RET locus are detected, regardless of whether these result or not in a functional oncogenic fusion [28].

Yang et al., tested FISH performance in RET-rearranged NSCLC, showing a high sensitivity for both KIF5B (95\%) and CCDC6 (95\%) fusion partners while reporting a lower percentage of RET-rearranged tumor cells for NCOA4 fusions, with sensitivity near $67 \%$ [29].

IHC can be used to measure RET protein expression, which may serve as a surrogate marker for RET fusions. Despite the growing number of diagnostic assays, the variability in their performance represents a significant challenge for harmonizing RET IHC testing. In previous studies, RET IHC has shown poor correlation with RET fusion status as determined by both FISH and RT-PCR, thus may not be considered a settled approach for the RET rearrangement detection [30]. Based on this data IHC is not currently recommended for RET fusion genes diagnostic purpose in clinical practice, while either FISH or NGS are needed.

Literature data suggest a wide range of RET-RNA expression levels in tumor samples by RT-q-PCR technology, considered an inadequate approach to detect either novel fusion partners or isoforms. Approximately 371 NSCLC patients, including 270 adenocarcinomas and 101 squamous cell carcinomas, were investigated to identify the clinical-pathological characteristics associated with the KIF5B/RET fusion. The RET fusion genes were detected 
only in three cases of adenocarcinomas analyzed by an RT-PCR-based assay while fusion partners were identified by direct sequencing [31].

In this scenario, NGS assays targeted-based approaches are able to identify either known or unknown mutations within gene panel reference range, ensuring higher diagnostic accuracy, faster turnaround time for low sample volumes, and lower costs. To date, several NGS panels for routine mutation analysis are commercially available enabling the simultaneous analysis of a plethora of clinically relevant hotspots in target genes, including RET. Targeted RNA sequencing (RNAseq) completes the DNA based one, allowing a more comprehensive approach for simultaneous detection of both gene fusions and somatic mutations in tumor samples. In detail, RNAseq assay approach allows the detection of chimeric RNA, the discrimination of splicing isoforms, and also the quantification of fusion transcripts. [32].

Most of the positive aspects of the RNAseq approach consists of its ability to allow an adequate detection of different RET fusion partners. Although we are conscious that this kind of information do not currently affect clinical decisions; however research data showed that specific fusion partners could predict different survival outcome in RETrearranged NSCLC patients. For example KIF5B-RET fusions seem highly dependent from EGFR signaling to promote enhanced cell growth, as compared both CCDC6-RET and NCOA4-RET fusions, in preclinical models [33].

Rich et al. showed as non-KIF5B-RET fusions contributed to anti-EGFR therapy resistance and [34] the same authors also reported specific RET fusions as mechanisms of resistance following exposure to third generation EGFR TKIs [34].

Finally, RNA seq allows the simultaneous testing of multiple biomarker beyond RET, including ALK, ROS1, NTRK, NRG1, Met ex 14 skipping, as recently suggested/recommended by the international ESMO guidelines [35].

NGS allows the detection of copy number alterations, gene rearrangements, and somatic mutations with $99 \%$ specificity and $>99 \%$ sensitivity for base substitutions at $\geq 5$ mutant allele frequency and $>95 \%$ sensitivity for copy number alterations [26].

Despite this evidence, recent clinical trials, LIBRETTO-001 and ARROW, leading to the regulatory approval of RET-TKIs in NSCLC, included patients who tested positive for RET fusion by the different methods used at each local facility (NGS, RT-PCR, or FISH), without requiring a central confirmatory NGS analysis. [32,36].

The European Society for Medical Oncology (ESMO) Translational Research and Precision Medicine Working Group (TR and PM WG) recently presented the recommendations for the routine detection of targetable RET rearrangements and mutations for the implementation of a rational approach in solid tumors. In particular, in NSCLC patients, multigene NGS is recommended. If NGS is not available, FISH or RT-PCR is indicated, depending on local availability, cost and/or number of tumor cells. In the case of a negative test result, NGS is always recommended. If a tissue sample is not available or exhausted, liquid biopsy may be considered [35-38]. Perhaps even more impactful is the ability for liquid biopsy to detect acquired RET rearrangements and/or mutations as resistance mechanisms alterations to targeted therapies in oncogene-addicted NSCLC [39,40].

An analysis of over 32,000 plasma samples collected from advanced cancer patients was performed to elucidate the co-occurring RET alterations oncogenic signaling pathways identified by liquid biopsy. This study was the largest cancer cohort with somatic activating $R E T$ alterations, reporting that non-KIF5B-RET fusions contributed to anti-EGFR therapy resistance [34]. However, the sensitivity of NGS analysis for the detection of RET fusions on plasma free-circulating nucleic acids is significantly lower as compared to tissue analysis, requiring further validation in dedicated studies. [41].

\section{Improving Patients Care: Mistakes in the Past and Adjustments for the Future}

In recent years, retrospective studies and small phase II clinical trials have evaluated several MKIs with contrasting results in terms of efficacy and toxicity [42,43] (Table 1). 
Cabozantinib is an MKI targeting RET, VEGFR2, mesenchymal-epithelial transition (MET) and KIT protooncogene receptor tyrosine kinase (c-KIT) [44]. A phase II study evaluated cabozantinib in 25 RET-rearranged NSCLC patients showing an ORR of $28 \%$, median PFS (mPFS) of 5.5 months and median OS (mOS) of 9.9 months. Drug discontinuation and dose reduction occurred in $8 \%$ and $73 \%$ of patients, respectively, suggesting that decreased inhibition caused by dose reduction may have influenced the treatment benefit [45].

Lenvatinib is an MKI with activity on RET, VEGFR1-2-3, platelet-derived growth factor receptor (PDGFR) and fibroblast growth factor receptor 1-2-3-4 (FGFR) [46]. Twenty five patients with RET-rearranged NSCLC were treated with lenvatinib showing an ORR of $16 \%$ and a mPFS of 7.3 months. Grade 3 treatment related events occurred in $92 \%$ of cases with three fatal events [47].

Vandetanib is another MKI that inhibits RET, VEGFR2-3 and EGFR pathways [48].

The Japanese phase II LURET trial evaluated vandetanib in 19 RET-rearranged NSCLC patients. The ORR, disease control rate (DCR), $\mathrm{mPFS}$ and $\mathrm{mOS}$ were $53 \%, 88 \%, 4.7$ and 11.1 months, respectively. The discontinuation rate was $21 \%$ and a dose reduction was necessary in more than $50 \%$ of patients [49]. A Korean phase II trial tested vandetanib in 18 RET fusion positive NSCLC patients, showing a lower ORR (18\%) compared to LURET study, but similar mPFS and mOS (4.5 months and 11.6 months) [50].

Table 1. Prospective/Retrospective Clinical Trials of Multikinase Inhibitors (MKIs) in RET-Rearranged Non-Small Cell Lung Cancer.

\begin{tabular}{|c|c|c|c|c|c|c|c|}
\hline Drug & First Author, Year & Phase & $\begin{array}{c}\text { Number of } \\
\text { Patients Enrolled }\end{array}$ & ORR (\%) & $\begin{array}{l}\text { Median PFS } \\
\text { (Months) }\end{array}$ & $\begin{array}{l}\text { Median OS } \\
\text { (Months) }\end{array}$ & $\begin{array}{c}\text { Adverse } \\
\text { Events } \\
\text { Grade } \geq 3\end{array}$ \\
\hline \multirow[t]{2}{*}{ Cabozantinib } & Drilon, 2016 [45] & II & 26 & $28 \%(12-49)$ & $5.5(3.8-8.4)$ & 9.9 (8.1-NR) & $47 \%$ \\
\hline & Gautschi, 2017 [42] & retrospective & 21 & $\begin{array}{c}37 \% \\
(16.3-61.6)\end{array}$ & $3.6(1.3-7.0)$ & $4.9(1.9-14.3)$ & NA \\
\hline \multirow[t]{2}{*}{ Lenvatinib } & Hida, 2019 [47] & II & 25 & $\begin{array}{c}16 \% \\
(4.5-36.1)\end{array}$ & $7.3(3.6-10.2)$ & NA & $92 \%$ \\
\hline & Gautschi, 2017 [42] & retrospective & 2 & $50 \%$ & NA & NA & NA \\
\hline \multirow[t]{3}{*}{ Vandetanib } & Lee, 2017 [50] & II & 18 & $18 \%$ & 4.5 & 11.6 & $28 \%$ \\
\hline & Yoh, 2017 [49] & II & 19 & $53 \%(28-77)$ & $4.7(2.8-8.5)$ & $11.1(9.4-\mathrm{NR})$ & \\
\hline & Gautschi, 2017 [42] & retrospective & 11 & $\begin{array}{c}18 \% \\
(2.3-51.8) \\
\end{array}$ & $2.9(1.0-6.4)$ & $10.2(2.4-\mathrm{NR})$ & NA \\
\hline \multirow[t]{2}{*}{ Sorafenib } & Horiike, 2016 [43] & II & 3 & $0 \%$ & NA & NA & $33 \%$ \\
\hline & Gautschi, 2017 [42] & retrospective & 2 & $0 \%$ & NA & NA & NA \\
\hline Sunitinib & Gautschi, 2017 [42] & retrospective & 10 & $22 \%(2.8-60)$ & $2.2(0.7-5.0)$ & $6.8(1.1-\mathrm{NR})$ & NA \\
\hline Nintedanib & $\begin{array}{c}\text { Gautschi, } 2017 \\
\text { [42] }\end{array}$ & retrospective & 2 & $50 \%$ & NA & NA & NA \\
\hline Ponatinib & $\begin{array}{c}\text { Gautschi, } 2017 \\
\text { [42] }\end{array}$ & retrospective & 2 & $0 \%$ & NA & NA & NA \\
\hline Alectinib & $\begin{array}{c}\text { Gautschi, } 2017 \\
\text { [42] }\end{array}$ & retrospective & 2 & $0 \%$ & NA & NA & NA \\
\hline Regorafenib & $\begin{array}{c}\text { Gautschi, } 2017 \\
\text { [42] }\end{array}$ & retrospective & 1 & $0 \%$ & NA & NA & NA \\
\hline
\end{tabular}

NA: not applicable; ORR: objective response rate. 
In summary, MKIs were associated with lower activity than that usually observed with targeted therapies in other molecularly selected NSCLC subgroups, with ORR ranging from 16 to $47 \%$ and mPFS of 4.54-7.3 months. The limited efficacy of MKIs in RET fusion positive NSCLC patients was essentially due to the not selective, wide spectrum of activity, including non-RET targets, such as EGFR and VEGFR2, resulting into high rates of toxicities and drug discontinuations. These data suggested an urgent need for more selective therapies, characterized by increased activity against RET kinase domain and diminished affinity for other kinases, in order to optimize risk/benefit ratio (Table 2).

Pralsetinib (BLU667) is a small molecule that strongly inhibits the RET kinase domain with activity against common oncogenic RET alterations, such as RET M918T, KIF5BRET and CCDC6-RET fusions [51]. The phase I/II ARROW trial evaluated pralsetinib in 92 pretreated and 29 untreated RET fusion positive NSCLC patients, with primary endpoints of safety and ORR. In pretreated patients, the ORR was 61\% (95\% CI 50-71), the median duration of response (mDOR) was not reached (NR) (95\% CI 15·2-not estimable) and mPFS was 17.1 months (95\% CI 8.3-22.1). Median OS was not reached. In treatmentnaive patients, ORR was 73\% (95\% CI 50-86), mDOR was 9.0 months (95\% CI 6.3-not estimable) and mPFS was 9.1 months (95\% CI 6.1-13.0). Interestingly, DCR was higher in platinum pretreated than in naïve patients (DCR 95\% versus $88 \%$, respectively). Median OS was not reached at a median follow-up of 13.6 months. Among eight pretreated patients with measurable central nervous system metastases at baseline, an intracranial response was observed in four patients (complete response in two). Intracranial responses were long lasting, without progression after six months. In terms of side effects, pralsetinib was well tolerated with mainly low grade toxicities ( $28 \%$ of patients had grade 3 AEs) [52]. The phase III AcceleRET Lung trial comparing pralsetinib to platinum-based chemotherapy with or without pembrolizumab as a first-line treatment in RET positive NSCLC is currently ongoing and results are awaited [53]. Pralsetinib is already approved by the Food and Drug Administration (FDA) and European Medicine Agency (EMA) for the treatment of adult patients with metastatic RET positive NSCLC.

Selpercatinib (LOXO-292) is an oral TKI inhibitor with potent and specific activity against the RET kinase domain, including multiple RET alterations such as fusions, activating point mutations and predicted acquired resistance mutations [54]. The phase I/II LIBRETTO-001 study evaluated the efficacy and safety of selpercatinib in 105 patients progressed to platinum-based chemotherapy and 39 treatment-naive. In pretreated patients, the ORR was $64 \%$ (95\% CI:54\%-73\%) with a mDOR of 17.5 months and a mPFS of 16.5 months. Interestingly, the major benefit was observed in the cohort of 39 treatmentnaive patients: the ORR was 85\% (95\% CI: 70\%-94\%) and, to date, the median duration of response and PFS have not been reached yet [32]. Among 11 patients with measurable intracranial disease at baseline, intracranial ORR was 91\% (95\% CI: 60-95) [55]. The safety profile was relatively favorable with most low grade adverse events and a treatment discontinuation rate of $1.7 \%$. The phase III LIBRETTO-431 trial comparing upfront selpercatinib to platinum-based chemotherapy with or without pembrolizumab in RET positive advanced NSCLC is currently ongoing [56].

Table 2. Prospective clinical trials of selective RET inhibitors in RET-rearranged non-small cell lung cancer.

\begin{tabular}{|c|c|c|c|c|c|c|c|c|c|c|}
\hline Drug & $\begin{array}{l}\text { First Author, } \\
\text { Year }\end{array}$ & Phase & Number of Patients & ORR & Intracranial RR & $\begin{array}{c}\text { Median Intracranial } \\
\text { PFS } \\
\text { (Months) }\end{array}$ & $\begin{array}{l}\text { Median DOR } \\
\text { (Months) }\end{array}$ & $\begin{array}{l}\text { Median PFS } \\
\text { (Months) }\end{array}$ & $\begin{array}{c}\text { Median OS } \\
\text { (Months) }\end{array}$ & $\begin{array}{c}\text { Adverse Events } \\
\quad \text { Grade } \geq 3\end{array}$ \\
\hline Selpercatinib & $\begin{array}{c}\text { Drilon, } 2020 \\
\text { [32] }\end{array}$ & I/II & $\begin{array}{c}105 \text { pretreated with } \\
\text { platinum } \\
\text { chemotherapy } \\
39 \text { untreated patients }\end{array}$ & $\begin{array}{c}64 \% \\
(54-73) \\
85 \% \\
(70-94)\end{array}$ & $\begin{array}{l}91 \%(59-100) \\
\text { (11 patients) }\end{array}$ & 13.7 (10.9-NE) & $\begin{array}{l}17.5(12.0-\mathrm{NE}) \\
\mathrm{NE}(12.0-\mathrm{NE})\end{array}$ & $\begin{array}{l}16.5(13.7-\mathrm{NE}) \\
\mathrm{NE}(13.8-\mathrm{NE})\end{array}$ & $\begin{array}{l}\text { NR } \\
\text { NR }\end{array}$ & $28 \%$ \\
\hline Pralsetinib & $\begin{array}{c}\text { Gainor } 2021 \\
\text { [52] }\end{array}$ & I/II & $\begin{array}{l}92 \text { pretreated with } \\
\text { platinum } \\
\text { chemotherapy } \\
29 \text { untreated patients }\end{array}$ & $\begin{array}{l}61 \%(50-71) \\
70 \%(50-86)\end{array}$ & $\begin{array}{l}56 \%(21-86) \\
\text { ( } 9 \text { patients) }\end{array}$ & & $\begin{array}{c}\text { NR } \\
9\end{array}$ & $\begin{array}{c}17.1(8.3-22.1) \\
9.1(6.1-13)\end{array}$ & $\begin{array}{l}\mathrm{NR} \\
\mathrm{NR}\end{array}$ & $48 \%$ \\
\hline
\end{tabular}

CI: confidence interval; NE: not be evaluated; NR: not reached; ORR: objective response rate; RR: response rate DOR: duration of response; PFS: progression free survival; OS: overall survival. 
Based on the aforementioned results, selpercatinib has already been approved in first and later lines by FDA and in second or later lines by EMA for the treatment of adult patients with metastatic RET positive NSCLC (Figure 1).

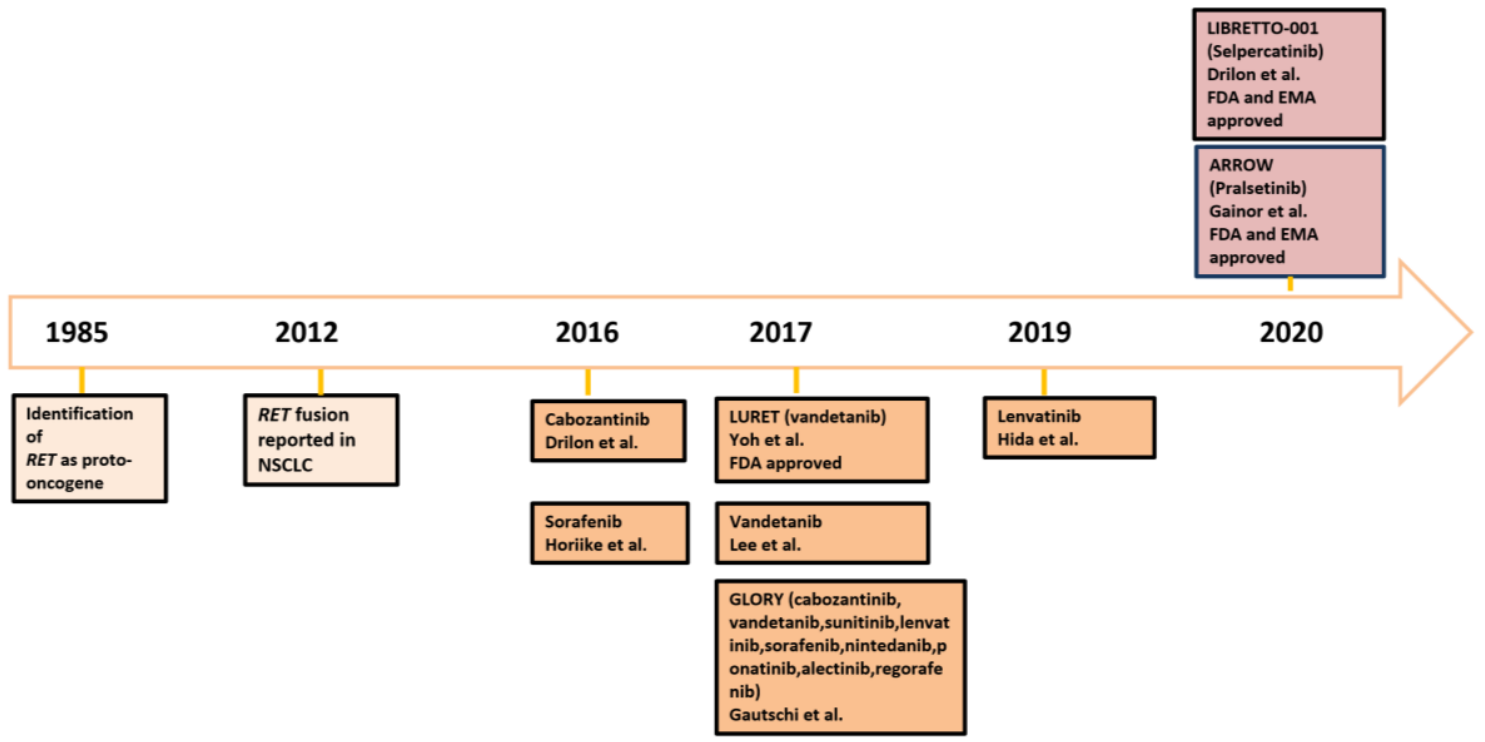

Figure 1. Timeline of advances in RET fusion NSCLC.

Beyond targeted therapies, retrospective studies have also demonstrated that RET rearrangement is significantly associated with increased levels of thymidylate synthase mRNA, leading to high ORR and long PFS under pemetrexed-based chemotherapy [9]. Drilon et al. showed that 18 RET-rearranged adenocarcinoma patients reported an ORR of $45 \%$ and a median PFS of 19 months under pemetrexed-based chemotherapy, similarly to what observed in ROS1- and ALK-rearranged disease [57]. Therefore, pemetrexed remains a reasonable treatment option for RET positive NSCLC. Otherwise, single agent immunotherapy, is mainly characterized by retrospective disappointing results, likely due to the low-medium levels of both programmed death ligand-1 (PD-L1) expression and tumor mutation burden (TMB) of this subgroup [58], while prospective data regarding chemotherapy and immunotherapy combinations are still lacking.

\section{Facing Acquired Resistance}

Despite the efficacy of selective RET-TKIs, acquired resistance invariably occurs during the treatment course, as known for other TKIs in oncogene-addicted NSCLC patients. The acquisition of secondary mutations within the target kinases represents one of the main mechanisms of resistance. In oncogene-addicted NSCLCs, secondary on-target mutations usually develop at the gatekeeper position or at the solvent front area of the kinase domain. These mutations, dynamically acquired under selective pressure of specific TKI, prevent their binding to the ATP-binding pocket, because of a steric interference, or by modifying the kinase structure, resulting in a constitutive receptor signaling activation, despite the TK inhibition [59].

RET gatekeeper mutations at the V804 residue (V804L and V804M) mainly occur as primary driver mutations causing intrinsic resistance to several MKIs in thyroid cancer [9]. However, they are also reported to have acquired resistance mechanisms emerging under MKIs therapy, as demonstrated by preclinical and clinical data [34,51,60,61]. Drilon et al. detected MDM2 proto-oncogene amplification as a possible mechanism of resistance to cabozantinib [9]. Nakaoku et al. identified the RET kinase domain mutation S904F in a RET-rearranged NSCLC patient after treatment with vandetanib, leading to increased kinase activity and drug resistance through allosteric effects [62]. 
Data on preclinical characterization and activity of both selpercatinib and pralsetinib showed not only their favorable properties regarding target specificity but also their capability to overcome resistance caused by V804M gatekeeper mutations [51,54]. Indeed both agents unconventionally bind $R E T$, avoiding any interference with gatekeeper mutations, while remaining susceptible to non-gatekeeper ones [63].

Since both Seplercatinib and Pralsetinib represent the current standard of care for advanced RET fusion-positive lung cancer, it is crucial to understand the novel mechanisms of resistance occurring in NSCLC patients, allowing the development of next-generation targeted therapies. Mutations at the solvent front of the ATP pocket have been identified as a mechanism of acquired resistance to selpercatinib and pralsetinib, causing a steric clash at the RET G810 position which results in a loss of binding potency. Solomon et al. recently analyzed circulating tumor DNA (ctDNA) and tissue samples from patients with RET fusion-positive NSCLC and RET mutation positive MTC who developed disease progression after initial response to selpercatinib. They reported RET G810R/S/C/V solvent front mutations as having acquired a resistance mechanism in three $R E T$ fusion-positive NSCLC and two RET-mutant MTC cases. Interestingly, these mutations occurred several months before the clinical disease progression [64]. Despite the potency of selpercatinib against the gatekeeper RET V804 mutations, authors reported also RET V804 and G810 mutations in trans in two cases and in cis in a minority of cells in one case [64].

When acquired mutations in the RET kinase are not identified, resistance could be driven by the activation of bypass signaling pathways. In the analysis by Lin et al. of serial tissue or plasma biopsies from a cohort of 18 patients with RET fusion-positive NSCLC after treatment with selpercatinib and pralsetinib, acquired RET mutations were identified only in two cases (10\%), both affecting the RET G810 residue in the kinase solvent front (G810C and G810S mutations). Interestingly, the majority of cases were driven by off-target, RET-independent mechanisms of resistance: three resistant cases $(15 \%)$ harbored acquired $M E T$ amplification without concurrent RET resistance mutations (resistance mechanism already detected in other subsets of oncogene-driven patients) and one had acquired KRAS amplification. No squamous or small cell transformation has been reported in this case series [65]. In a preliminary analysis of pralsetinib resistance mechanisms from the ARROW trial, RET-mediated resistance resulted similarly uncommon, with only $4 / 42$ patients developing on-target RET G810 and L730 mutations (in the roof region of the ATP-binding site) [66].

Rosen and colleagues detected MET amplification in post-treatment biopsies of four patients with RET fusion-positive NSCLC treated with selpercatinib. MET amplification seems to be sufficient to cause selpercatinib resistance in vitro, and the addition of the MET inhibitor crizotinib showed promising antitumoral activity. Importantly, the combination of selpercatinib and crizotinib in a series of single-patient protocols demonstrated clinical efficacy and tolerability, with one response lasting 10 months [67]. Some published clinical cases report NTRK3 fusion as an acquired resistance mechanism to selpercatinib [63] and the acquisition of tertiary MET resistance to selpercatinib and capmatinib in a patient with secondary MET amplification as initial resistance to selpercatinib [68]. Other offtarget resistance mechanisms involving EGFR and AXL signaling have been identified in preclinical studies $[69,70]$.

These data, even if not sufficient to define the true incidence of on-target and offtarget mechanisms, highlight a different acquired resistance distribution compared to other oncogene-addicted subgroups, such as $E G F R$ and $A L K$, where the reported incidence of on-target secondary mutations is considerably higher than that observed in RET-rearranged ones [71,72]. Further investigations are needed to elucidate the entire spectrum of resistance mechanisms occurring under selective RET-TKIs, including any potential differences between selpercatinib and pralsetinib, in order to develop novel and effective targeted strategies in the near future. 


\section{Future Perspectives and Conclusions}

Different trials specifically dedicated to RET-rearranged NSCLC patients are ongoing and the results eagerly awaited (Table 3).

Table 3. Ongoing Clinical Trials Investigating RET-TKIs in RET Fusion Positive NSCLC.

\begin{tabular}{|c|c|c|c|c|c|c|}
\hline Trial & $\begin{array}{c}\text { Experimental } \\
\text { Arm }\end{array}$ & Comparator Arm & Setting & Phase & Primary Endpoint & Status \\
\hline NCT04161391 & TPX-0046 & - & $\mathrm{N}$ line & $1 / 2$ & DLTs, MTD, ORR & Recruiting \\
\hline $\begin{array}{l}\text { NCT04683250 } \\
\text { (MARGARET) }\end{array}$ & TAS0953/HM06 & - & $\mathrm{N}$ line & $1 / 2$ & MTD, RP2D, ORR & Recruiting \\
\hline $\begin{array}{l}\text { NCT03037385 } \\
\text { (ARROW) }\end{array}$ & $\begin{array}{l}\text { pralsetinib } \\
\text { (BLU-667) }\end{array}$ & - & 1-N line & $1 / 2$ & $\begin{array}{l}\text { MTD, } \mathrm{N}^{\circ} \text { of patients } \\
\text { with adverse events } \\
\text { and serious adverse } \\
\text { events, ORR }\end{array}$ & Recruiting \\
\hline NCT01639508 & Cabozantinib & - & 1-N line & 2 & ORR & Recruiting \\
\hline NCT03780517 & BOS172738. & - & $\mathrm{N}$ line & 1 & TEAE, MTD, RP2D & $\begin{array}{l}\text { Active, not } \\
\text { recruiting }\end{array}$ \\
\hline $\begin{array}{l}\text { NCT04268550 } \\
\text { (Lung-MAP) }\end{array}$ & Selpercatinib & - & $\mathrm{N}$ line & 2 & ORR & Recruiting \\
\hline $\begin{array}{c}\text { NCT03157128 } \\
\text { (LIBRETTO-001) }\end{array}$ & Selpercatinib & - & $\mathrm{N}$ line & $1 / 2$ & MTD, RP2D, ORR & Recruiting \\
\hline $\begin{array}{l}\text { NCT04131543 } \\
\text { (CRETA) }\end{array}$ & Cabozantinib & - & 2-N line & 2 & $\mathrm{RR}$ & Recruiting \\
\hline NCT04194944 & Selpercatinib & $\begin{array}{c}\text { Platinum- } \\
\text { Pemetrexed with or } \\
\text { without } \\
\text { Pembrolizumab }\end{array}$ & 1 line & 3 & PFS & Recruiting \\
\hline $\begin{array}{l}\text { NCT04302025 } \\
\text { (NAUTIKA1) }\end{array}$ & $\begin{array}{c}\text { SOC } \\
\text { chemotherapy }+ \\
\text { Pralsetinib }\end{array}$ & - & $\begin{array}{l}\text { Neoadj- } \\
\text { Adjuvant }\end{array}$ & 2 & MPR & Recruiting \\
\hline NCT04222972 & Pralsetinib & $\begin{array}{l}\text { Platinum-based } \\
\text { chemotherapy with } \\
\text { or without } \\
\text { pembrolizumab }\end{array}$ & 1 line & 3 & PFS & Recruiting \\
\hline $\begin{array}{c}\text { NCT04819100 } \\
\text { (LIBRETTO-432) }\end{array}$ & Selpercatinib & Placebo & Adjuvant & 3 & EFS & Recruiting \\
\hline $\begin{array}{l}\text { NCT02314481 } \\
\text { (DARWINII) }\end{array}$ & Alectinib & - & $\mathrm{N}$ line & 2 & PFS & Recruiting \\
\hline $\begin{array}{l}\text { NCT04591431 } \\
\text { (ROME) }\end{array}$ & Alectinib & - & 2 line & 2 & ORR & Recruiting \\
\hline $\begin{array}{l}\text { NCT03178552 } \\
\text { (B-FAST) }\end{array}$ & Alectinib & - & 1 line & $2 / 3$ & ORR & Recruiting \\
\hline
\end{tabular}

DLTs: dose-limiting toxicities; MTD: maximum tolerated dose; ORR: objective response rate; RP2D: Recommended Phase 2 dose; TEAE: treatment-emergent adverse events; SOC: standard of care; EFS: Event-Free Survival.

Novel RET inhibitors active against both solvent front and gatekeeper resistance mutations, are currently under clinical development. TPX-0046, a novel next-generation RET/SRC inhibitor, showed potent in vitro and in vivo activity against diverse RET alterations, including RET G810C/S/R solvent front mutation, even if lacking V804Mgatekeeper mutation inhibition [73]. A phase I/II trial is active to better determine its safety, tolerability and efficacy (NCT04161391) [74]. BOS172738 (DS-5010), already demonstrated differentiated safety profile and clinical efficacy against gate-keeper RET alterations 
within a phase I study, and is under further investigation [75]. LOX-18228, LOX-19260, TAS0953/HM06 are other RET-TKIs in the early phase of clinical development [76,77].

Finally, moving to the early stage disease, whether perioperative targeted treatment with RET inhibitors might improve survival of RET fusion positive NSCLC patients is an appealing topic under clinical evaluation. LIBRETTO-432, indeed, is a phase 3, randomized, double-blind, trial studying the efficacy and safety of adjuvant selpercatinib versus placebo in patients with RET fusion-positive stage IB-IIIA NSCLC following radiotherapy/surgery and other adjuvant therapies if indicated (NCT04819100) [78]. NAUTIKA1 is a phase II trial evaluating neoadjuvant and adjuvant targeted treatments in resectable stage II and III NSCLC with driver alterations, including RET-rearranged patients who will receive perioperative pralsetinib [79].

In conclusion, RET fusions now represent an established therapeutic target in NSCLC. Despite the relative rarity of this molecular alteration, renewed efforts are needed to implement molecular testing and to ensure the accessibility to the best available treatment option. Indeed, non-specific MKIs achieved limited clinical benefit and modest disease control and have been now replaced by novel selective TKIs, as pralsetinib and selpercatinib, leading to updated therapeutic algorithms for RET-rearranged NSCLC patients. Emerging challenges, such as detecting and overcoming acquired resistance, have to be faced in order to develop innovative treatment/combination strategies and further improve survival outcomes of RET-rearranged NSCLC patient.

Author Contributions: Conceptualization, M.L.R., V.B. and A.L.; writing-original draft preparation, M.L.R., V.B. and A.L.; writing-review and editing, M.L.R., V.B., A.L., F.P. and S.N.; supervision, F.P. and S.N.; project administration. All authors have read and agreed to the published version of the manuscript.

Funding: This research received no external funding.

Institutional Review Board Statement: Not applicable.

Informed Consent Statement: Not applicable.

Conflicts of Interest: Maria Lucia Reale has received personal fees (as consultant and/or speaker bureau) from Eli Lilly and MSD, unrelated to the current work. Francesco Passiglia has received personal fees (as consultant and/or speaker bureau) from MSD, AstraZeneca, Boehringer Ingelheim, BMS, and Pfizer, unrelated to the current work. Silvia Novello reports personal fees (as speaker bureau or adviser) from Eli Lilly, MSD, Roche, BMS, Takeda, Pfizer, Astra Zeneca and Boehringer Ingelheim, unrelated to the current work. The other The authors have nothing to disclose.

\section{References}

1. Kris, M.G.; Johnson, B.E.; Berry, L.D.; Kwiatkowski, D.J.; Iafrate, A.J.; Wistuba, I.I.; Varella-Garcia, M.; Franklin, W.A.; Aronson, S.L.; Su, P.F.; et al. Using Multiplexed Assays of Oncogenic Drivers in Lung Cancers to Select Targeted Drugs. JAMA 2014, 311, 1998-2006. [CrossRef]

2. Chu, Q.S. Targeting non-small cell lung cancer: Driver mutation beyond epidermal growth factor mutation and anaplastic lymphoma kinase fusion. Ther. Adv. Med. Oncol. 2020, 12, 1758835919895756. [CrossRef]

3. Marsh, D.J.; Learoyd, D.L.; Andrew, S.D.; Krishnan, L.; Pojer, R.; Richardson, A.L.; Delbridge, L.; Eng, C.; Robinson, B.G. Somatic mutations in the RET proto-oncogene in sporadic medullary thyroid carcinoma. Clin. Endocrinol. 1996, 44, 249-257. [CrossRef]

4. Cancer Genome Atlas Research Network. Integrated genomic characterization of papillary thyroid carcinoma. Cell 2014, 159, 676-690. [CrossRef]

5. Takeuchi, K.; Soda, M.; Togashi, Y.; Suzuki, R.; Sakata, S.; Hatano, S.; Asaka, R.; Hamanaka, W.; Ninomiya, H.; Uehara, H.; et al. RET, ROS1 and ALK fusions in lung cancer. Nat. Med. 2012, 18, 378-381. [CrossRef]

6. Wang, R.; Hu, H.; Pan, Y.; Li, Y.; Ye, T.; Li, C.; Luo, X.; Wang, L.; Li, H.; Zhang, Y.; et al. RET fusions define a unique molecular and clinicopathologic subtype of non-small-cell lung cancer. J. Clin. Oncol. 2012, 30, 4352-4359. [CrossRef]

7. Song, Z.; Yu, X.; Zhang, Y. Clinicopathologic characteristics, genetic variability and therapeutic options of RET rearrangements patients in lung adenocarcinoma. Lung Cancer 2016, 101, 16-21. [CrossRef]

8. Klempner, S.J.; Bazhenova, L.A.; Braiteh, F.S.; Nikolinakos, P.G.; Gowen, K.; Cervantes, C.M.; Chmielecki, J.; Greenbowe, J.R.; Ross, J.S.; Stephens, P.J.; et al. Emergence of RET rearrangement co-existing with activated EGFR mutation in EGFR-mutated NSCLC patients who had progressed on first- or second-generation EGFR TKI. Lung Cancer 2015, 89, 357-359. [CrossRef] [PubMed] 
9. Drilon, A.; Hu, Z.I.; Lai, G.G.Y.; Tan, D.S.W. Targeting RET-driven cancers: Lessons from evolving preclinical and clinical landscapes. Nat. Rev. Clin. Oncol. 2018, 15, 150. [CrossRef]

10. Plaza-Menacho, I. Structure and function of RET in multiple endocrine neoplasia type 2. Endocr.- Relat. Cancer 2018, 25, T79-T90. [CrossRef] [PubMed]

11. Kawai, K.; Takahashi, M. Intracellular RET Signaling Pathways Activated by GDNF. Cell Tissue Res. 2020, 382, 113-123. [CrossRef]

12. Plaza-Menacho, I.; Burzynski, G.M.; de Groot, J.W.; Hofstra, R.M. Current Concepts in RET-Related Genetics, Signaling and Therapeutics. Trends Genet. 2006, 22, 627-636. [CrossRef]

13. Plaza-Menacho, I.; Mologni, L.; Sala, E.; Gambacorti-Passerini, C.; Magee, A.I.; Links, T.P.; Hofstra, R.M.; Barford, D.; Isacke, C.M. Sorafenib functions to potently suppress RET tyrosine kinase activity by direct enzymatic inhibition and promoting RET lysosomal degradation independent of proteasomal targeting. J. Biol. Chem. 2007, 282, 29230-29240. [CrossRef]

14. Plaza-Menacho, I.; Morandi, A.; Mologni, L.; Boender, P.; Gambacorti-Passerini, C.; Magee, A.I.; Hofstra, R.M.; Knowles, P.; McDonald, N.Q.; Isacke, C.M. Focal adhesion kinase (FAK) binds RET kinase via its FERM domain, priming a direct and reciprocal RET-FAK transactivation mechanism. J. Biol. Chem. 2011, 286, 17292-17302. [CrossRef]

15. Takahashi, M.; Ritz, J.; Cooper, G.M. Activation of a novel human transforming gene, ret, by DNA rearrangement. Cell 1985, 42 , 581-588. [CrossRef]

16. Grieco, M.; Santoro, M.; Berlingieri, M.T.; Melillo, R.M.; Donghi, R.; Bongarzone, I.; Pierotti, M.A.; Della Porta, G.; Fusco, A.; Vecchio, G. PTC is a novel rearranged form of the ret proto-oncogene and is frequently detected in vivo in human thyroid papillary carcinomas. Cell 1990, 60, 557-563. [CrossRef]

17. Thein, K.Z.; Velcheti, V.; Mooers, B.H.M.; Wu, J.; Subbiah, V. Precision therapy for RET-altered cancers with RET inhibitors. Trends Cancer 2021, 7, 1074-1088. [CrossRef] [PubMed]

18. Sipple, J.H. Multiple endocrine neoplasia type 2 syndromes: Historical perspectives. Henry Ford Hosp. Med. J. 1984, 32, $219-221$.

19. Subbiah, V.; Roszik, J. Towards precision oncology in RET-aberrant cancers. Cell Cycle 2017, 16, 813-814. [CrossRef]

20. Subbiah, V.; Yang, D.; Velcheti, V.; Drilon, A.; Meric-Bernstam, F. State-of-the-Art Strategies for Targeting RET-Dependent Cancers. J. Clin. Oncol. 2020, 38, 1209-1221. [CrossRef]

21. Wiesner, T.; He, J.; Yelensky, R.; Esteve-Puig, R.; Botton, T.; Yeh, I.; Lipson, D.; Otto, G.; Brennan, K.; Murali, R. Kinase fusions are frequent in Spitz tumours and spitzoid melanomas. Nat. Commun. 2014, 5, 3116. [CrossRef]

22. Ballerini, P.; Struski, S.; Cresson, C.; Prade, N.; Toujani, S.; Deswarte, C.; Dobbelstein, S.; Petit, A.; Lapillonne, H.; Gautier, E.F.; et al. RET fusion genes are associated with chronic myelomonocytic leukemia and enhance monocytic differentiation. Leukemia 2012, 26, 2384-2389. [CrossRef]

23. Le Rolle, A.F.; Klempner, S.J.; Garrett, C.R.; Seery, T.; Sanford, E.M.; Balasubramanian, S.; Ross, J.S.; Stephens, P.J.; Miller, V.A.; Ali, S.M.; et al. Identification and characterization of RET fusions in advanced colorectal cancer. Oncotarget 2015, 6, 28929-28937. [CrossRef]

24. Ogino, H.; Yano, S.; Kakiuchi, S.; Yamada, T.; Ikuta, K.; Nakataki, E.; Goto, H.; Hanibuchi, M.; Nishioka, Y.; Ryan, A.; et al. Novel dual targeting strategy with vandetanib induces tumor cell apoptosis and inhibits angiogenesis in malignant pleural mesothelioma cells expressing RET oncogenic rearrangement. Cancer Lett. 2008, 265, 55-66. [CrossRef]

25. Takeuchi, K. Discovery Stories of RET Fusions in Lung Cancer: A Mini-Review. Front. Physiol. 2019, 10, 216. [CrossRef]

26. Benayed, R.; Offin, M.; Mullaney, K.; Sukhadia, P.; Rios, K.; Desmeules, P.; Ptashkin, R.; Won, H.; Chang, J.; Halpenny, D.; et al. High Yield of RNA Sequencing for Targetable Kinase Fusions in Lung Adenocarcinomas with No Mitogenic Driver Alteration Detected by DNA Sequencing and Low Tumor Mutation Burden. Clin. Cancer Res. 2019, 25, 4712-4722. [CrossRef]

27. Tsuta, K.; Kohno, T.; Yoshida, A.; Shimada, Y.; Asamura, H.; Furuta, K.; Kushima, R. RET-rearranged non-small-cell lung carcinoma: A clinicopathological and molecular analysis. Br. J. Cancer 2014, 110, 1571-1578. [CrossRef]

28. Radonic, T.; Geurts-Giele, W.R.R.; Samsom Kris, G. RET Fluorescence In Situ Hybridization Analysis Is a Sensitive but Highly Unspecific Screening Method for RET Fusions in Lung Cancer. J. Thorac. Oncol. 2021, 16, 798-806. [CrossRef]

29. Yang, S.R.; Aypar, U.; Rosen, E.Y.; Mata, D.A.; Benayed, R.; Mullaney, K.; Jayakumaran, G.; Zhang, Y.; Frosina, D.; Drilon, A.; et al. A Performance Comparison of Commonly Used Assays to Detect RET Fusions. Clin. Cancer Res. 2021, 27, 1316-1328. [CrossRef]

30. Go, H.; Jung, Y.J.; Kang, H.W.; Park, I.K.; Kang, C.H.; Lee, J.W.; Ju, Y.S.; Seo, J.S.; Chung, D.H.; Kim, Y.T. Diagnostic method for the detection of KIF5B-RET transformation in lung adenocarcinoma. Lung Cancer 2013, 82, 44-50. [CrossRef]

31. Yokota, K.; Sasaki, H.; Okuda, K.; Shimizu, S.; Shitara, M.; Hikosaka, Y.; Moriyama, S.; Yano, M.; Fujii, Y. KIF5B/RET fusion gene in surgically-treated adenocarcinoma of the lung. Oncol. Rep. 2012, 28, 1187-1192. [CrossRef]

32. Drilon, A.; Oxnard, G.R.; Tan, D.S.W.; Loong, H.H.F.; Johnson, M.; Gainor, J.; McCoach, C.E.; Gautschi, O.; Besse, B.; Cho, B.C.; et al. Efficacy of Selpercatinib in RET Fusion-Positive Non-Small-Cell Lung Cancer. N. Engl. J. Med. 2020, 383, 813-824. [CrossRef] [PubMed]

33. Das, T.K.; Cagan, R.L. KIF5B-RET Oncoprotein Signals through a Multi-kinase Signaling Hub. Cell Rep. 2017, $20,2368-2383$. [CrossRef] [PubMed]

34. Rich, T.A.; Reckamp, K.L.; Chae, Y.K.; Doebele, R.C.; Iams, W.T.; Oh, M.; Raymond, V.M.; Lanman, R.B.; Riess, J.W.; Stinchcombe, T.E.; et al. Analysis of cell-free DNA from 32,989 advanced cancers reveals novel co-occurring activating RET alterations and oncogenic signaling pathway aberrations. Clin. Cancer Res. 2019, 25, 5832-5842. [CrossRef] 
35. Belli, C.; Penault-Llorca, F.; Ladanyi, M.; Normanno, N.; Scoazec, J.Y.; Lacroix, L.; Reis-Filho, J.S.; Subbiah, V.; Gainor, J.F.; Endris, V.; et al. ESMO recommendations on the standard methods to detect RET fusions and mutations in daily practice and clinical research. Ann. Oncol. 2021, 32, 337-350. [CrossRef]

36. Gainor, J.F.; Curigliano, G.; Kim, D.-W.; Lee, D.H.; Besse, B.; Baik, C.S.; Doebele, R.C.; Cassier, P.A.; Lopes, G.; Tan, D.S.; et al. Registrational Dataset from the Phase I/II ARROW Trial of Pralsetinib (BLU-667) in Patients (Pts) With Advanced RET Fusion+ Non-Small Cell Lung Cancer (NSCLC). J. Clin. Oncol. 2020, 38, 9515-9515. [CrossRef]

37. Reckamp, K.L.; Patil, T.; Kirtane, K.; Rich, T.A.; Espenschied, C.R.; Weipert, C.M.; Raymond, V.M.; Santana-Davila, R.; Doebele, R.C.; Baik, C.S. Duration of targeted therapy in patients with advanced none-small-cell lung cancer identifed by circulating tumor DNA analysis. Clin. Lung Cancer 2020, 21, 545-552. [CrossRef]

38. Mack, P.C.; Banks, K.C.; Espenschied, C.R.; Burich, R.A.; Zill, O.A.; Lee, C.E.; Riess, J.W.; Mortimer, S.A.; Talasaz, A.; Lanman, R.B.; et al. Spectrum of driver mutations and clinical impact of circulating tumor DNA analysis in non-small cell lung cancer: Analysis of over 8000 cases. Cancer 2020, 126, 3219-3228. [CrossRef]

39. Malapelle, U.; Tiseo, M.; Vivancos, A.; Kapp, J.; Serrano, M.J.; Tienamm, M. Liquid Biopsy for Biomarker Testing in Non-Small Cell Lung Cancer: A European Perspective. J. Mol. Pathol. 2021, 2, 22. [CrossRef]

40. Dagogo-Jack, I.; Stevens, S.E.; Lin, J.J.; Nagy, R.; Ferris, L.; Shaw, A.T.; Gainor, J.F. Emergence of a RET V804M gatekeeper mutation during treatment with vandetanib in RET-rearranged NSCLC. J. Thorac. Oncol. 2018, 13, e226-e227. [CrossRef]

41. Hofman, P. What Is New in Biomarker Testing at Diagnosis of Advanced Non-Squamous Non-Small Cell Lung Carcinoma? Implications for Cytology and Liquid Biopsy. J. Mol. Pathol. 2021, 2, 15. [CrossRef]

42. Gautschi, O.; Milia, J.; Filleron, T.; Wolf, J.; Carbone, D.P.; Owen, D.; Camidge, R.; Narayanan, V.; Doebele, R.C.; Besse, B.; et al Targeting RET in Patients With RET-Rearranged Lung Cancers: Results From the Global, Multicenter RET Registry. J Clin Oncol. 2017, 35, 1403-1410. [CrossRef] [PubMed]

43. Horiike, A.; Takeuchi, K.; Uenami, T.; Kawano, Y.; Tanimoto, A.; Kaburaki, K.; Tambo, Y.; Kudo, K.; Yanagitani, N.; Ohyanagi, F.; et al. Sorafenib treatment for patients with RET fusion-positive non-small cell lung cancer. Lung Cancer. 2016, 93, 43-46. [CrossRef] [PubMed]

44. Yakes, F.M.; Chen, J.; Tan, J.; Yamaguchi, K.; Shi, Y.; Yu, P.; Qian, F.; Chu, F.; Bentzien, F.; Cancilla, B.; et al. Cabozantinib (XL184), a Novel MET and VEGFR2 Inhibitor, Simultaneously Suppresses Metastasis, Angiogenesis, and Tumor Growth. Mol. Cancer Ther. 2011, 10, 2298-2308. [CrossRef] [PubMed]

45. Drilon, A.; Rekhtman, N.; Arcila, M.; Wang, L.; Ni, A.; Albano, M.; Van Voorthuysen, M.; Somwar, R.; Smith, R.S.; Montecalvo, J.; et al. Cabozantinib in patients with advanced RET-rearranged non-small-cell lung cancer: An open-label, single-centre, phase 2, single-arm trial. Lancet Oncol. 2016, 17, 1653-1660. [CrossRef]

46. Okamoto, K.; Kodama, K.; Takase, K.; Sugi, N.H.; Yamamoto, Y.; Iwata, M.; Tsuruoka, A. Antitumor activities of the targeted multi-tyrosine kinase inhibitor lenvatinib (E7080) against RET gene fusion-driven tumor models. Cancer Lett. 2013, 340, 97-103. [CrossRef] [PubMed]

47. Hida, T.; Velcheti, V.; Reckamp, K.L.; Nokihara, H.; Sachdev, P.; Kubota, T.; Nakada, T.; Dutcus, C.E.; Ren, M.; Tamura, T. A phase 2 study of lenvatinib in patients with RET fusion-positive lung adenocarcinoma. Lung Cancer. 2019, 138, 124-130. [CrossRef] [PubMed]

48. Carlomagno, F.; Vitagliano, D.; Guida, T.; Ciardiello, F.; Tortora, G.; Vecchio, G.; Ryan, A.J.; Fontanini, G.; Fusco, A.; Santoro, M. ZD6474, an Orally Available Inhibitor of KDR Tyrosine Kinase Activity, Efficiently Blocks Oncogenic RET Kinases. Cancer Res. 2002, 62, 7284-7290.

49. Yoh, K.; Seto, T.; Satouchi, M.; Nishio, M.; Yamamoto, N.; Murakami, H.; Nogami, N.; Nosaki, K.; Kohno, T.; Tsuta, K.; et al Final survival results for the LURET phase II study of vandetanib in previously treated patients with RET-rearranged advanced non-small cell lung cancer. Lung Cancer 2021, 155, 40-45. [CrossRef]

50. Lee, S.-H.; Lee, J.-K.; Ahn, M.-J.; Kim, D.W.; Sun, J.M.; Keam, B.; Kim, T.M.; Heo, D.S.; Ahn, J.S.; Choi, Y.L.; et al. Vandetanib in pretreated patients with advanced non-small cell lung cancer-harboring RET rearrangement: A phase II clinical trial. Ann. Oncol. 2017, 28, 292-297. [CrossRef]

51. Subbiah, V.; Gainor, J.F.; Rahal, R.; Brubaker, J.D.; Kim, J.L.; Maynard, M.; Hu, W.; Cao, Q.; Sheets, M.P.; Wilson, D.; et al. Precision Targeted Therapy with BLU-667 for RET-Driven Cancers. Cancer Discov. 2018, 8, 836-849. [CrossRef] [PubMed]

52. Gainor, J.F.; Curigliano, G.; Kim, D.W.; Lee, D.H.; Besse, B.; Baik, C.S.; Doebele, R.C.; Cassier, P.A.; Lopes, G.; Tan, D.S.W.; et al Pralsetinib for RET fusion-positive non-small-cell lung cancer (ARROW): A multi-cohort, open-label, phase 1/2 study. Lancet Oncol. 2021, 22, 959-969. [CrossRef]

53. Besse, B.; Felip, E.; Clifford, C.; Louie-Gao, M.; Green, J.; Turner, C.D.; Popat, S. AcceleRET Lung: A phase III study of first-line pralsetinib in patients (pts) with RET-fusion+ advanced/metastatic non-small cell lung cancer (NSCLC). J. Clin. Oncol. 2020, 38 (Suppl. 15), TPS9633. [CrossRef]

54. Subbiah, V.; Velcheti, V.; Tuch, B.B.; Ebata, K.; Busaidy, N.L.; Cabanillas, M.E.; Wirth, L.J.; Stock, S.; Smith, S.; Lauriault, V.; et al. Selective RET Kinase Inhibition for Patients with RET-Altered Cancers. Ann. Oncol. 2018, 29, 1869-1876. [CrossRef]

55. Subbiah, V.; Gainor, J.F.; Oxnard, G.R.; Tan, D.S.W.; Owen, D.H.; Cho, B.C.; Loong, H.H.; McCoach, C.E.; Weiss, J.; Kim, Y.J.; et al Intracranial Efficacy of Selpercatinib in RET Fusion-Positive Non-Small Cell Lung Cancers on the LIBRETTO-001 Trial. Clin. Cancer Res. 2021, 27, 4160-4167. [CrossRef] [PubMed] 
56. Goto, K.; Wolf, J.; Elamin, Y. LIBRETTO-431: Selpercatinib in Treatment-Naïve Patients with RET Fusion-Positive Non-Small Cell Lung Cancer (NSCLC). J. Thorac. Oncol. 2021, 16, S228-S229. [CrossRef]

57. Drilon, A.; Bergagnini, I.; Delasos, L.; Sabari, J.; Woo, K.M.; Plodkowski, A.; Wang, L.; Hellmann, M.D.; Joubert, P.; Sima, C.S.; et al. Clinical outcomes with pemetrexed-based systemic therapies in RET-rearranged lung cancers. Ann. Oncol. 2016, 27, 1286-1291. [CrossRef] [PubMed]

58. Mazieres, J.; Drilon, A.; Lusque, A.; Mhanna, L.; Cortot, A.B.; Mezquita, L.; Thai, A.A.; Mascaux, C.; Couraud, S.; Veillon, R.; et al. Immune checkpoint inhibitors for patients with advanced lung cancer and oncogenic driver alterations: Results from the IMMUNOTARGET registry. Ann. Oncol. 2019, 30, 1321-1328. [CrossRef] [PubMed]

59. Lin, J.J.; Shaw, A.T. Resisting Resistance: Targeted Therapies in Lung Cancer. Trends Cancer 2016, 2, 350-364. [CrossRef]

60. Carlomagno, F.; Guida, T.; Anaganti, S.; Vecchio, G.; Fusco, A.; Ryan, A.J.; Billaud, M.; Santoro, M. Disease associated mutations at valine 804 in the RET receptor tyrosine kinase confer resistance to selective kinase inhibitors. Oncogene 2004, 23, 6056-6063. [CrossRef]

61. Wirth, L.J.; Kohno, T.; Udagawa, H.; Matsumoto, S.; Ishii, G.; Ebata, K.; Tuch, B.B.; Zhu, E.Y.; Nguyen, M.; Smith, S.; et al. Emergence and targeting of acquired and hereditary resistance to multikinase RET inhibition in patients with RET-altered cancer. JCO Precis. Oncol. 2019, 3, 1-7. [CrossRef] [PubMed]

62. Nakaoku, T.; Kohno, T.; Araki, M.; Niho, S.; Chauhan, R.; Knowles, P.P.; Tsuchihara, K.; Matsumoto, S.; Shimada, Y.; Mimaki, S.; et al. A secondary RET mutation in the activation loop conferring resistance to vandetanib. Nat. Commun. 2018, 9, 625. [CrossRef] [PubMed]

63. Subbiah, V.; Shen, T.; Terzyan, S.S.; Liu, X.; Hu, X.; Patel, K.P.; Hu, M.; Cabanillas, M.; Behrang, A.; Meric-Bernstam, F.; et al. Structural basis of acquired resistance to selpercatinib and pralsetinib mediated by non-gatekeeper RET mutations. Ann. Oncol. 2021, 32, 261-268. [CrossRef] [PubMed]

64. Solomon, B.J.; Tan, L.; Lin, J.J.; Wong, S.Q.; Hollizeck, S.; Ebata, K.; Tuch, B.B.; Yoda, S.; Gainor, J.F.; Sequist, L.V.; et al. RET Solvent Front Mutations Mediate Acquired Resistance to Selective RET Inhibition in RET-Driven Malignancies. J. Thorac. Oncol. 2020, 15, 541-549. [CrossRef]

65. Lin, J.J.; Liu, S.V.; McCoach, C.E.; Zhu, V.W.; Tan, A.C.; Yoda, S.; Peterson, J.; Do, A.; Prutisto-Chang, K.; Dagogo-Jack, I.; et al. Mechanisms of resistance to selective RET tyrosine kinase inhibitors in RET fusion-positive non-small-cell lung cancer. Ann. Oncol. 2020, 31, 1725-1733. [CrossRef]

66. Gainor, J.; Curigliano, G.; Doebele, R.C.; Lin, J.; Ou, S.; Miller, S.; Turner, C.; Subbiah, V. OA05.02 analysis of resistance mechanisms to pralsetinib in patients with RET fusion-positive non-small cell lung cancer (NSCLC) from the ARROW study. J. Thorac. Oncol. 2021, 16, S5. [CrossRef]

67. Rosen, E.Y.; Johnson, M.L.; Clifford, S.E.; Somwar, R.; Kherani, J.F.; Son, J.; Bertram, A.A.; Davare, M.A.; Gladstone, E.; Ivanova, E.V.; et al. Overcoming MET-Dependent Resistance to Selective RET Inhibition in Patients with RET Fusion-Positive Lung Cancer by Combining Selpercatinib with Crizotinib. Clin. Cancer Res. 2021, 27, 34-42. [CrossRef] [PubMed]

68. Zhu, V.W.; Zhang, S.S.; Zhang, J.; Swensen, J.; Xiu, J.; Ou, S.I. Acquired Tertiary MET Resistance (MET D1228N and a Novel LSM8MET Fusion) to Selpercatinib and Capmatinib in a Patient with KIF5B-RET-positive NSCLC With Secondary MET Amplification as Initial Resistance to Selpercatinib. J. Thorac. Oncol. 2021, 16, e51-e54. [CrossRef]

69. Chang, H.; Sung, J.H.; Moon, S.U.; Kim, H.S.; Kim, J.W.; Lee, J.S. EGF Induced RET Inhibitor Resistance in CCDC6-RET Lung Cancer Cells. Yonsei Med. J. 2017, 58, 9-18. [CrossRef] [PubMed]

70. Nelson-Taylor, S.K.; Le, A.T.; Yoo, M.; Schubert, L.; Mishall, K.M.; Doak, A.; Varella-Garcia, M.; Tan, A.C.; Doebele, R.C. Resistance to RET-Inhibition in RET-Rearranged NSCLC Is Mediated by Reactivation of RAS/MAPK Signaling. Mol. Cancer Ther. 2017, 16, 1623-1633. [CrossRef]

71. Schoenfeld, A.J.; Chan, J.M.; Kubota, D.; Sato, H.; Rizvi, H.; Daneshbod, Y.; Chang, J.C.; Paik, P.K.; Offin, M.; Arcila, M.E.; et al. Tumor Analyses Reveal Squamous Transformation and Off-Target Alterations as Early Resistance Mechanisms to First-line Osimertinib in EGFR-Mutant Lung Cancer. Clin. Cancer Res. 2020, 26, 2654-2663. [CrossRef] [PubMed]

72. Gainor, J.F.; Dardaei, L.; Yoda, S.; Friboulet, L.; Leshchiner, I.; Katayama, R.; Dagogo-Jack, I.; Gadgeel, S.; Schultz, K.; Singh, M.; et al. Molecular Mechanisms of Resistance to First- and Second-Generation ALK Inhibitors in ALK-Rearranged Lung Cancer. Cancer Discov. 2016, 6, 1118-1133. [CrossRef]

73. Drilon, A.; Rogers, E.; Zhai, D.; Deng, W.; Zhang, X.; Lee, D.; Ung, J.; Whitten, J.; Zhang, H.; Liu, J.; et al. TPX-0046 is a novel and potent RET/SRC inhibitor for RET-driven cancers. Ann. Oncol. 2019, 30 (Suppl. 5), v190-v191. [CrossRef]

74. Study of TPX-0046, A RET/SRC Inhibitor in Adult Subjects With Advanced Solid Tumors Harboring RET Fusions or Mutations. Available online: https:/ / clinicaltrials.gov/ct2/show /NCT04161391 (accessed on 9 January 2022).

75. Schoffski, P.; Chul Cho, B.; Italiano, A.; Loong, H.F.; Massard, C.; Rodriguez, L.M.; Shih, J.; Subbiah, V.; Verlingue, L.; Andreas, K.; et al. BOS172738, a highly potent and selective RET inhibitor, for the treatment of RET-altered tumors including RET-fusion+ NSCLC and RET-mutant MTC: Phase 1 study results. J. Clin. Oncol. 2021, 39 (Suppl. 15), 3008. [CrossRef]

76. Study of RET Inhibitor TAS0953/HM06 in Patients with Advanced Solid Tumors with RET Gene Abnormalities (MARGARET). Available online: https:/ / clinicaltrials.gov/ct2/show / NCT04683250 (accessed on 9 January 2022). 
77. Gabrielle, R.; Kolakowski, Anderson, E.D.; Brandhuber, B.J.; Condroski, K.R.; Gomez, E.B.; Irvin, T.C.; Kumar, M.; Patel, N.A.; Watson, F.D. Pre-clinical characterization of potent and selective next-generation RET inhibitors [abstract]. In Proceedings of the American Association for Cancer Research Annual Meeting 2021, Online, 10-15 April and 17-21 May 2021; AACR: Philadelphia, PA, USA, 2021.

78. Goldman, J.; Besse, B.; Wu, Y.; Yang, J.C.; Paz-Ares, L.; Drilon, A.; Johnson, M.; Xia, M.; Chao, B.H.; Tsuboi, M. P01.01 LIBRETTO432: A Placebo-Controlled Phase 3 Study of Adjuvant Selpercatinib in Stage IB-IIIA RET Fusion-Positive NSCLC. J. Thorac. Oncol. 2021, 16, S975-S976. [CrossRef]

79. A Study of Alectinib, Entrectinib, Vemurafenib Plus Cobimetinib, or Pralsetinib in Patients With Resectable Stages II-III Non-Small Cell Lung Cancer With ALK, ROS1, NTRK, BRAF V600, or RET Molecular Alterations. Available online: https:/ / clinicaltrials. gov/ct2/show / NCT04302025 (accessed on 9 January 2022). 